\title{
Situation of European SMEs in the olive oil and table olive area. Survey
}

\author{
By Rosa de la Viesca, Elena Fernández (*), Silvia Fernández and Javier Salvador
}

\author{
Centro de Información y Documentación Científica (CINDOC), CSIC \\ c/ Joaquín Costa 22 - 28002 Madrid
}

\section{RESUMEN}

La PYME europea en el sector del aceite de oliva y aceituna. Encuesta sobre la situación del sector.

En este trabajo, se realiza un estudio de la PYME europea en el sector olivarero para detectar las principales necesidades que tienen las empresas en información técnica, participación en proyectos de investigación, formación, Tecnologías de Información y Comunicación (TIC), calidad, impacto ambiental, etc. Los datos se obtuvieron a través de encuestas enviadas a empresas de Alemania, Francia, España, Grecia, Italia, Portugal y Turquía. Los resultados obtenidos muestran que las TIC tienen un nivel razonable de implantación en este sector industrial. Así mismo, las empresas encuestadas manifiestan tener gran interés en actividades de formación e información en la legislación relacionada con el sector, el control de calidad y el marketing.

PALABRAS-CLAVE: Aceite de oliva - Aceituna - Cursos de formación - PYME - TICs.

\section{SUMMARY}

Situation of European SMEs in the olive oil and table olive area. Survey.

A study of the situation of European Small and Medium Enterprises (SMEs) in the olive oil and table olive sector is carried out in order to find their main needs in the following aspects: information, participation in Research, Development and Innovation $(\mathrm{R}+\mathrm{D}+\mathrm{l})$ programmes, Information and Communication Technologies (ICTs) implementation, quality control, environmental impacts, etc. The data used in this study were obtained through questionnaires sent to SMEs in France, Germany, Greece, Italy, Portugal, Spain and Turkey. The results obtained show: a reasonable acceptance of ICTs, a high interest in training courses on the most recent and pertinent legislation, and in product quality improvement and marketing.

KEY-WORDS: ICTS - Olive oil - SMES - Table olives - Training courses.

\section{INTRODUCTION}

The production of olive oil has a very high economic and social value in the Mediterranean countries and the beneficial effects of the Mediterranean diet, based mainly on the consumption of olive oil as source of fats, has led to a great interest in the European Union both to improve the competitiveness of the olive oil producers and the knowledge by the potential consumers on the healthy results obtained when changing other edible fats by olive oil ${ }^{1,2,3,4,5,6}$.

Spain, Italy and Greece are the major producing countries of olive oil and table olives. Most of the enterprises in this sector in those countries are small, only $0.6 \%$ of them have more than 200 employees, and suffer from a lack of technological development.

Olive oil world trade represents hardly $3 \%$ of the total of edible fats. The main competitor to olive oil is seed oil that can partially substitute olive oil in consumption and is much cheaper.

In order to have an overview of the current situation, a survey has been carried out to analyse the situation of the SMEs in the olive oil and table olive sector, from several points of view, and to determine their needs in: training, information, R\&D, introduction of ICTs, quality, marketing, etc.

Next a short overview of the general situation of the olive oil industrial sector in the countries where the study has been developed is given:

- The olive oil sector in Spain (Average annual production 808,014 tons for the years 1991-2004) is of a great economic importance; it is even a monoculture in many regions ${ }^{7,8,9}$. Although Spain is the first producer there are only 17 Protected Designations of Origin (PDOs): Aceite de Baix Ebre-Montsià, Aceite de Mallorca, Aceite de Monterrubio, Aceite de Terra Alta, Aceite del Bajo Aragón, Baena, Gata-Hurdes, Les Garrigues, Ciurana, Montes de Granada, Montes de Toledo, Poniente de Granada, Priego de Córdoba, Sierra de Cádiz, Sierra de Cazorla, Sierra de Segura, y Sierra Mágina.

- Italy is the second world producer of olive oil $(527,929$ tons is the average annual production for years 1991-2003), and the first exporter of packaged olive oil. There are more than two million farms and 6,000 oil-mills that operate in Italy, and $75 \%$ are located in southern Italy ${ }^{10,11}$. It has the following 30 Protected Designations of Origin: Alto Crotonese, Aprutino Pescarese, Brisighella, Bruzio, Canino, Chianti Classico, Cilento, Collina di Brindisi, Colline di Romagna, Colline Salernitane, Colline Teatine, Dauno, Garda, Laghi Lombardi, Lametia, Molise, Monte Etna, Monti Iblei, Penisola Sorrentina, Pretuziano delle Colline Teramane, Riviera Ligure, Sabina, Terra di Bari, Terra d'Otranto, Terre di Siena, Toscano, Umbria, Val di Mazara and Valli Trapanesi. 
- Olive-growing in Greece covers a surface area of about one million hectares, with an olive oil production over 450.000 tons per year, $15 \%$ of the world production, $80-85 \%$ of which are extra virgin oils ${ }^{12,13}$. According to the Greek Association of Olive Mill Owners, there are 2,400 operating oil-mills, mainly small sized. Greece exports about 100 thousand tonnes of oil, mostly «in bulk» and mainly sent to Italy. It is the third olive oil-producing country in the World. The good quality level of the Hellenic production is confirmed by the recognition of the following 23 Protected Designation of Origin: Apokoronas Hanion Kritis, Archanes Iraklio Kritis, Exeretiko partheno eleolado: "Thrapsano", Finiki Lakonias, Kalamata, Kefalonia, Kolymvari Hanion Kritis, Kranidi Argolidas, Krokees, Lakonias Hania Kritis, Lakonia Lesbos, Lygourgio Asklipiou, Olympia, Petrina Lakonias, Peza Iraklio Kritis, Preveza, Rhodos, Samos, Sitia Lasithi Kritis, Thassos, Viannos Iraklio Kritis, Vorios Mylopotamos Rethymnis Kritis and Zakynthos.

- Portugal is the forth producer of the EU (36.307 tons as average annual production for years 1991-2003) ${ }^{14}$. The 6 Designations of Origin are the following: Azeite de Moura, Azeite de Tras-os-Montes, Azeite do Ribateio, Azeites da Beira Interior (Azeite da Beira Alta, Azeite da Beira Baixa) and Azeites do Norte Alentejano.

- France is the fifth olive-producing country in the EU (2,921 tons average annual production for years 1991-2003), after Spain, Italy, Greece and Portugal ${ }^{15}$ It has 5 Regulatory Councils of Designations of Origin for extra virgin olive oil: Huile d'olive d'Aix-en-Provence, Huile d'olive de Haute-Provence, Huile d'olive de la Vallée des Baux-de-Provence and Huile d'olive de Nyons.

- Turkey has also been considered in this work. With an annual production of 98,857 tons of olive oil, Turkey is the 4th world olive producer ${ }^{16}$.

- Among the EU non-producing countries of olive oil, Germany and United Kingdom are the main consumers, with 24,000 tand 23,000 trespectively. Germany has been taken into consideration in the survey, as they have an important packaging, marketing and distribution activities.

\section{SURVEY}

In the design of the questionnaire (see Annex I), used to survey the producing SMEs in the countries selected in this study and some non producing German SMEs, the following specifications were taken into consideration:
- It should not be too long (11 blocks of questions)

- The answers requested should only be: yes or no.

- It would be translated into every language of the countries surveyed

The total number of contacts made, mainly SMEs, by country was:

Table I

\begin{tabular}{l|c}
\hline \multicolumn{1}{c|}{ Country } & $\mathbf{N}^{0}$ of Contacts \\
\hline Spain & 500 \\
\hline France & 180 \\
\hline Italy & 178 \\
\hline Greece & 152 \\
\hline Germany & 70 \\
\hline Turkey & 30 \\
\hline Portugal & 48 \\
\hline Total & $\mathbf{1 , 1 5 8}$ \\
\hline
\end{tabular}

The total number of contacted companies, cooperatives and associations was 1,158 , and the replies, that were completed by the SMEs and associations, were 700 . The answer rate achieved was $60.14 \%$.

The questionnaires were distributed using different forms of communication, so as to gain access to the largest number of SMEs:

- Personal contact, mainly at the food fairs attended

- Telephone

- Fax

- Post

- e-mail: after a telephone call, sending them the survey as an attachment or even within the main body of the e-mail to facilitate the process

Among the surveyed SMEs, the most interested and receptive in answering the questionnaires, were those who already had some ICTs implemented, owned a computer, had e-mail and used basic computer tools.

All data were collected and implemented into a database, with 87 fields, of which 13 were fields of general identification of the enterprises, and 74 fields related to the questions asked in the questionnaire.

\subsection{Analysis of the results of the survey}

\section{Country distribution}

The distribution of the 700 filled questionnaires obtained by country is shown in table II. It includes 
the number of SMEs in the olive oil sector and the number of those that were really surveyed. The data corresponding to the 4 blocks of questions included in this group distributed by country seemed to follow the same trend as the aggregated data.

Table II

\begin{tabular}{l|c|c}
\hline \multicolumn{1}{c|}{ Country } & Olive oil SMEs & SMEs surveyed \\
\hline Spain & 2000 & 320 \\
\hline Italy & 6000 & 145 \\
\hline Greece & 2400 & 131 \\
\hline Portugal & 904 & 31 \\
\hline France & 70 & 26 \\
\hline Turkey & 150 & 12 \\
\hline Germany & 500 & 35 \\
\hline Total & - & 700 \\
\hline
\end{tabular}

The percentage of error for the total of the surveys carried out in the different countries was $3.6 \%$.

\section{Subject distribution}

The results of the surveys will be analysed by six groups of questions:

1. Information and Communication Technologies (ICTs): blocks of questions 1 to 4

2. Legislation and Food Regulations: block of questions 5

3. Environment: block of questions 6

4. Quality Issues: blocks of questions 7 and 8

5. Training: blocks of questions 9

6. Clients and Suppliers: blocks of questions 10

\section{Information and communication technologies, ICTS}

It has been set out in four different sections:

a) Infrastructures in ICTs. Most of the companies $(93 \%)$ have at least one personal computer, (88\%) with Internet connection and (86\%) e-mail. The programs more extensively used are those on management (Excel 83\%, sales and accounting 73\%). The programs less used are those on web page creation and graphic design (14\%). In spite of it, nearly half of those surveyed (48\%) have a company web page. (See Figure 1).

b) Use of computers. According to the survey, an increasing number of SMEs frequently uses computers: Internet and e-mail (83\%). They also agree that these tools are or might be helpful to obtain information of interest to the company (93\%), to contact different administrations (81\%), clients

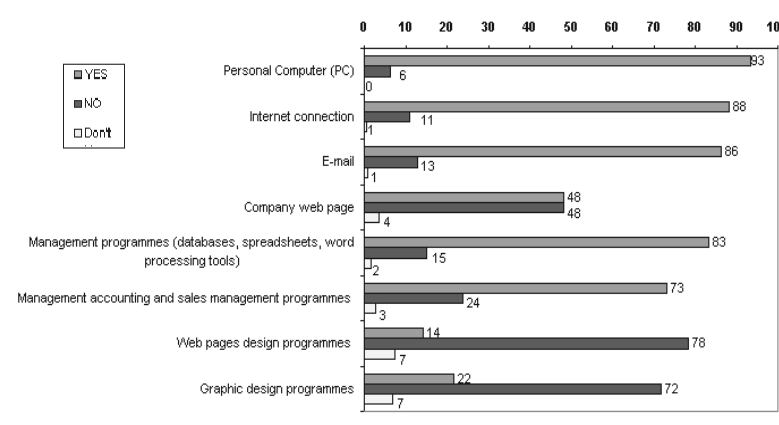

Figure 1

ITC infraestructures in SMEs. Global Data (\%).

and suppliers (89\%). An $86 \%$ believes that these tools could allow them to improve the company image and obtain more publicity for their products, as well as increase their competitiveness and visibility. A high percentage, $53 \%$, still finds ICTs complex and expensive to install and use, and $66 \%$ are afraid of security problems, as well as computer viruses. $64 \%$ also state that their clients and suppliers use these technologies. (See figure 2)

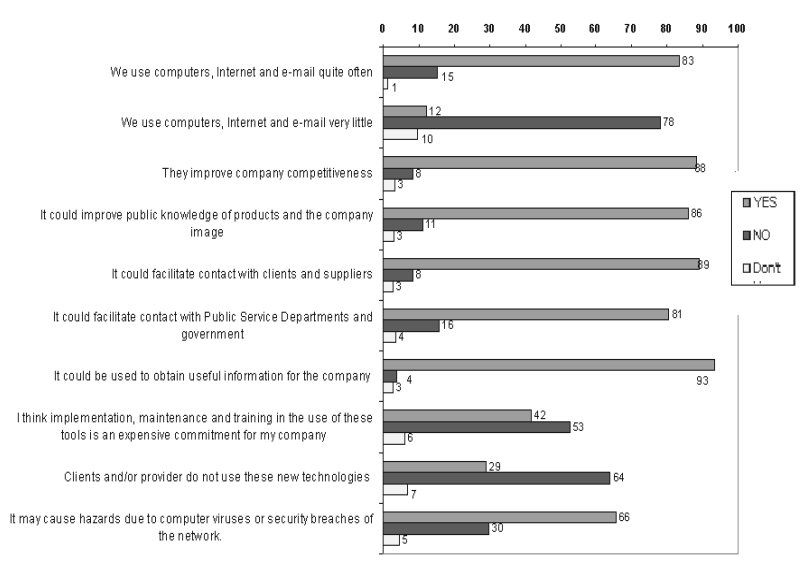

Figure 2

Use of ITC in SMEs. Global Data (\%).

c) ICT training requirements. The "web page design" training program has raised the greatest interest of all training offers, keeping in mind that only $48 \%$ of the SMEs have a web page. (See Figure 3 )

d) Type of information desired. Documents on legislation and regulations is the most demanded type of information ( $88 \%$ ), followed by information on public subsidies and grants (84\%), and price lists in different markets (84\%). The less attractive information was that related to research projects, patents and scientific databases (61\%). This result evidences a fact of great concern: the gap between Research and Development (R\&D) organisations 


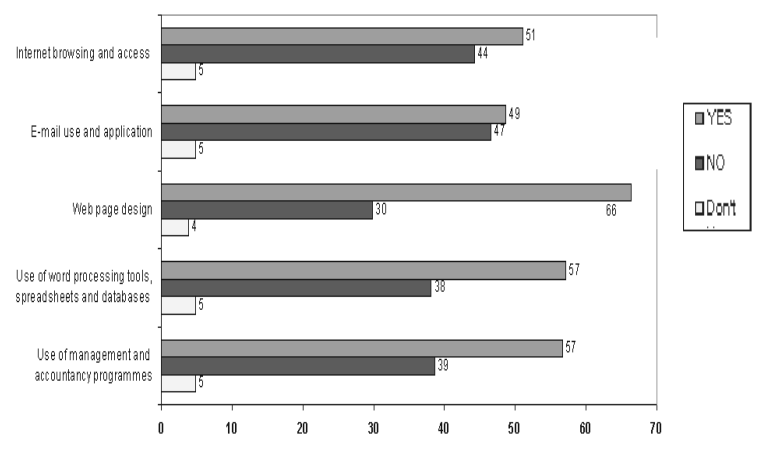

Figure 3

Improvement of knowledge in ITC. Global Data (\%).

and the process of technological innovation that should be developed in SMEs. (See Figure 4)

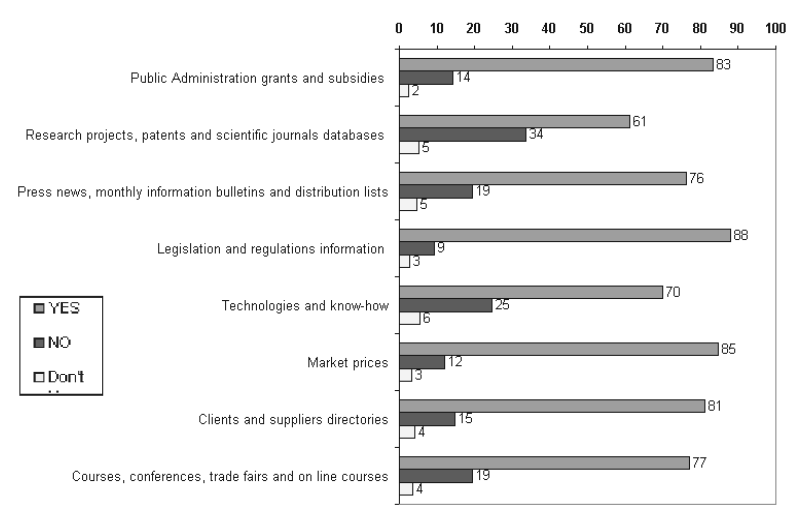

Figure 4

Information of interest for SMEs. Global Data (\%).

\section{Legislation and food regulations}

$85 \%$ of the enterprises surveyed showed interest on information on health safety and on legislation related to olive oil and table olive, $84 \%$ on labelling

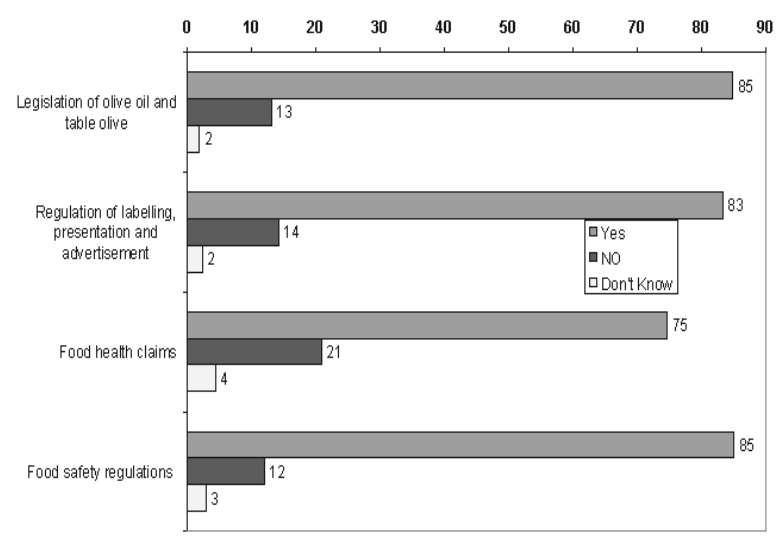

Figure 5

Information needs on Legislation and Regulation. Global Data (\%). regulations, product presentation and publicity, and $74 \%$ on subjects related to the introduction of health claims in food. (See figure 5).

\section{Environment}

From the companies that were surveyed, $78 \%$ are interested in increasing their general knowledge in environmental legislation (see Figure 6)

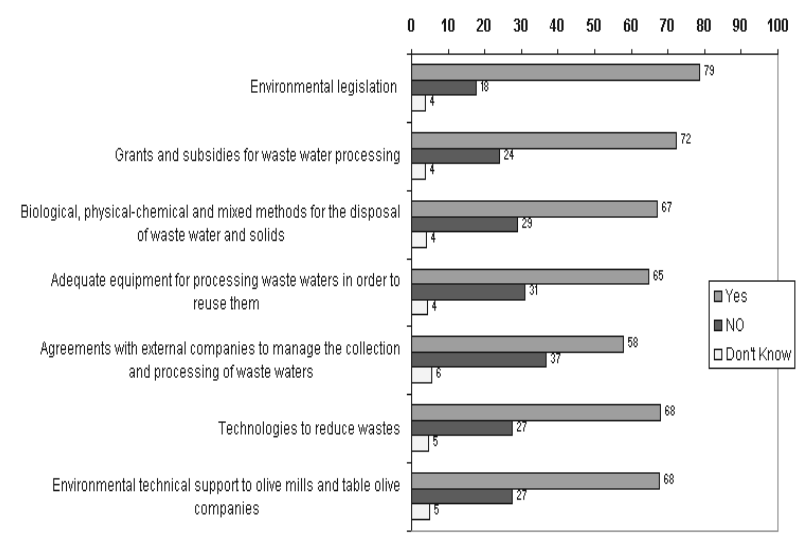

Figure 6

Environment Needs. Global Data (\%).

\section{Quality issues}

It has been broken down into two sets of questions:

a) Basic quality systems introduced in the company. The data obtained shows that $62 \%$ of the companies have some kind of quality control system. Within this percentage, the Hazard Analysis and Critical Control Point System is the most used (63\%). (See Figure 7)

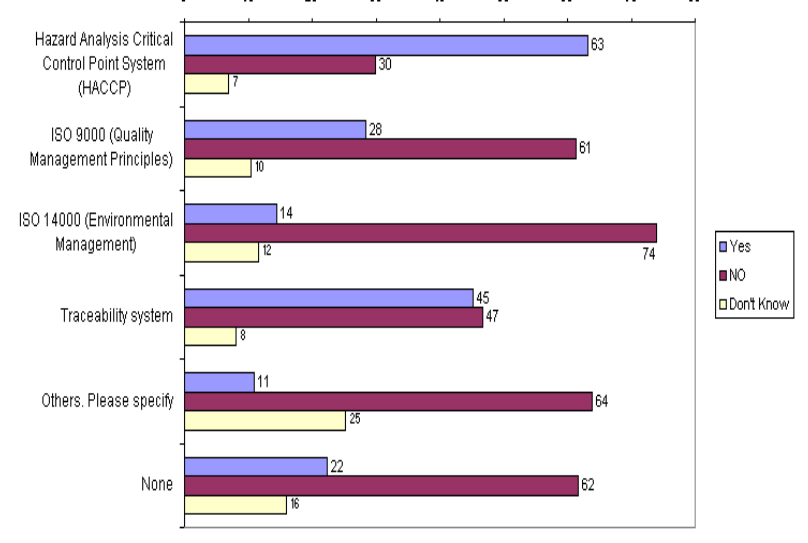

Figure 7

Quality Systems Implemented in SMEs. Global Data (\%).

b) Other aspects related to areas of quality control introduced in the companies. $76 \%$ of the SMEs show interest in the application of new 
technologies in their production processes. As for the regular controls carried out, the physical-chemical, biochemical and microbiological controls are those mostly performed (69\%). (See Figure 8)

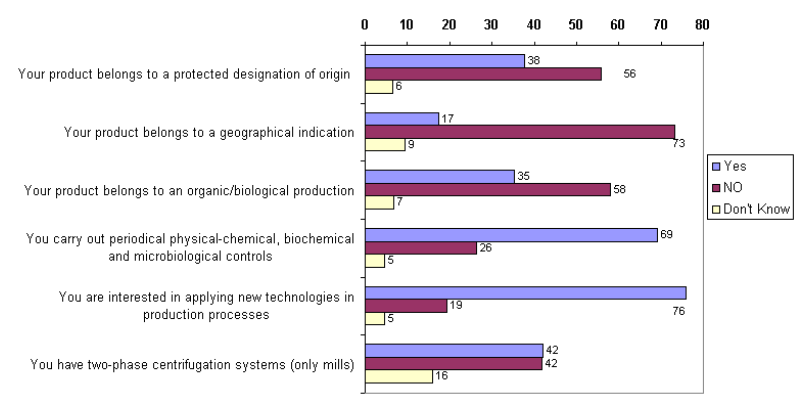

Figure 8

Other Quality Indicators Implemented in SMEs. Global Data (\%).

\section{Training}

This group has 12 questions that cover a wide range of possible courses basically in two subjects: food quality and marketing techniques. The results obtained are the following:

a) Courses on quality: $88 \%$ of the companies show a great interest in courses on overall quality improvement techniques: $78 \%$ would be interested in sensorial analysis training courses (training in olive and olive oil tasting), $77 \%$ in analytical measurements in quality control and $68 \%$ in processing technologies.

b) Marketing courses: $81 \%$ of the companies surveyed are interested in marketing and commercial promotion training courses, and $76 \%$ in product export courses. (See Figure 9)

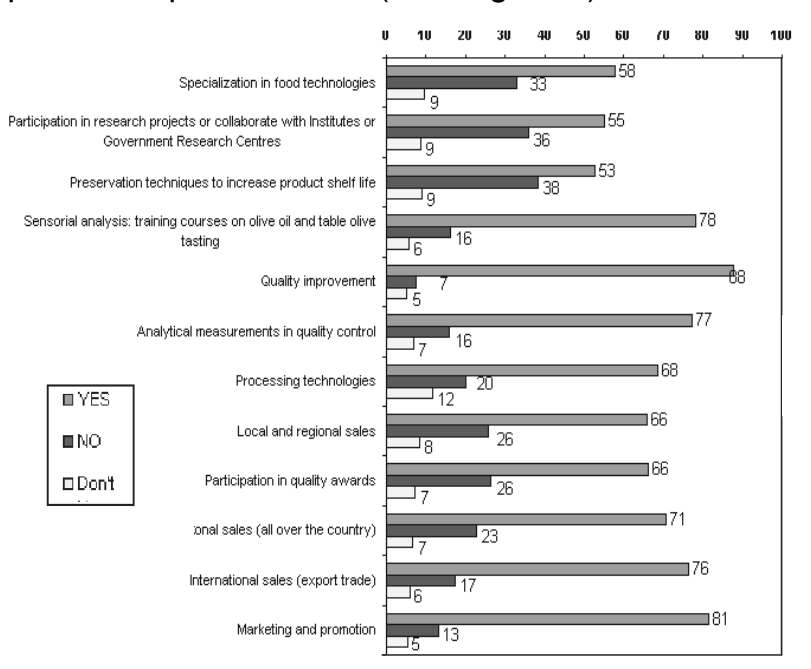

Figure 9

Training and Activities of Interest for SMEs. Global Data (\%).

\section{Clients and suppliers}

With respect to the communication channels employed by SMEs to approach their clients and suppliers, a $93 \%$ prefers personal face-to-face interviews and only a $34 \%$ uses Internet to communicate. (See Figure 10)

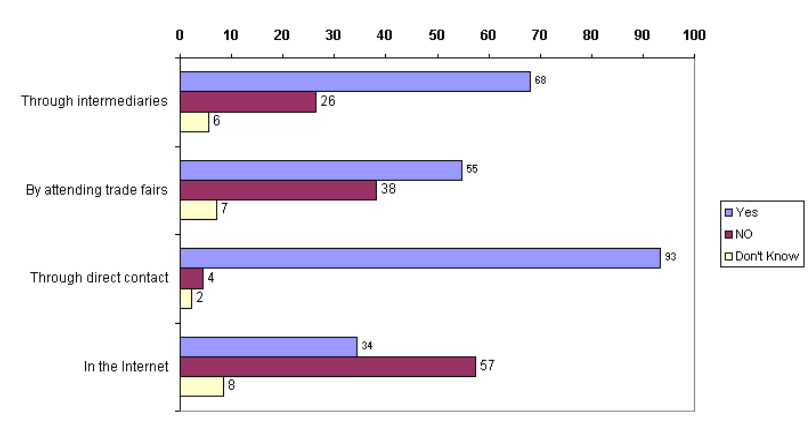

Figure 10

Comunication with clients and suppliers. Global Data (\%).

\subsection{ANALYSIS BY SIZE}

The distribution of SMEs surveyed by size is presented in Table III and the distribution by country in Figure 11:

Table III

\begin{tabular}{c|c}
\hline Number of employees & $\begin{array}{c}\text { Percentage of companies } \\
\text { surveyed }\end{array}$ \\
\hline $1-5$ & $56 \%$ \\
\hline $6-50$ & $35 \%$ \\
\hline+50 & $91 \%$ \\
\hline
\end{tabular}

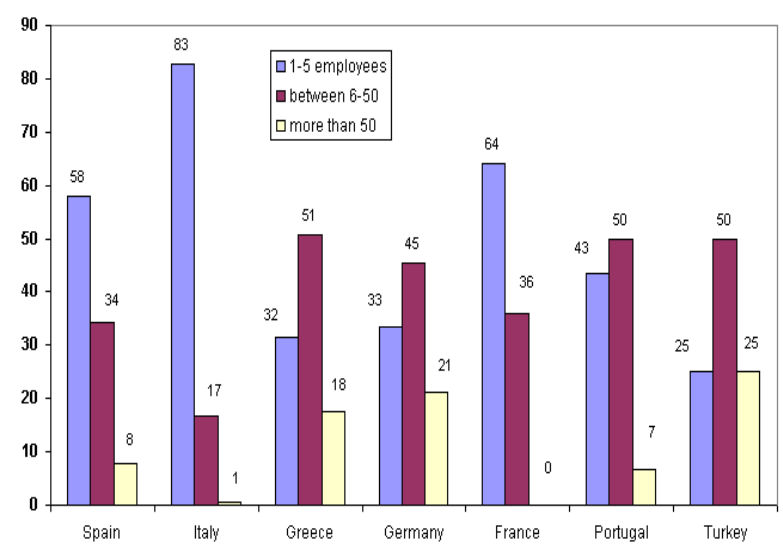

Figure 11

Distribution of SMEs by country and number of employees (\%). 
In Spain, Italy and France, most of the companies contacted are very small (1-5 employees) with $58 \%$, $82 \%$ and $64 \%$ percentages respectively. It has to be remarked, once again, that in the case of Germany, the figures are not comparable, as the German SMEs contacted are only packaging and distribution companies.

\subsection{ANALYSIS BY ACTIVITY}

The distribution of the SMEs by type of activity is:

Table IV

\begin{tabular}{l|c|c}
\hline \multicolumn{1}{c|}{ Activity } & Number $(-)$ & $\%$ \\
\hline Producers & 2000 & 320 \\
\hline Packagers & 6000 & 145 \\
\hline Distributors & 2400 & 131 \\
\hline
\end{tabular}

$\left({ }^{\star}\right)$ The total number obtained adding the number of companies by activity is higher than 700 as many companies have more than one activity.

There are no significant differences in the replies obtained that will allow to establish differences according to the type of activities.

\section{CONCLUSIONS OF THE STUDY}

The main ideas extracted after carrying out this work can be synthesized in the following points:

\section{Information and Communication Technologies (ICTS)}

- The enterprises have at least a computer (93\%), Internet connection (88\%) and e-mail $(86 \%)$, with $83 \%$ of use.

- $93 \%$ claims that these tools are very useful to communicate with administrations, clients and suppliers.

- Half of the SMEs (53\%) believes that ICTs are expensive and need more qualified staff.

- Only $48 \%$ has a web page.

- In the ranking of acceptance of the proposed courses, "creation of web pages" is on the top $(66 \%)$.

- A vast majority, $89 \%$ of SMEs, chooses the information on legislation and regulations as their main topic, followed by information on public grants and subsidies (84\%) and clients and suppliers directories (84\%).

- Only $61 \%$ shows an interest on being informed in research projects, patents and scientifictechnological databases

\section{Food Legislation and Regulations}

- The enterprises show a high level of interest in increasing their knowledge in these subjects $(74-85 \%)$

\section{Environment}

- $78 \%$ of the SMEs wish to increase their knowledge on environmental legislation and regulations, and $72 \%$ on the support systems for waste processing.

\section{Quality}

- Only $62 \%$ have some kind of basic quality control system.

- The system most used is related to the «Hazard Analysis and Critical Control Points" $(63 \%)$.

- The traceability system follows with $45 \%$ and the ISO 9001 and 14001 with $28 \%$ and $14 \%$ respectively

\section{Training}

- $88 \%$ of the companies wish to attend courses to improve the quality of the products. The most demanded are the following: Sensorial analysis (78\%), Analytical measurements (77\%), Processing technologies (68\%), Participation in R\&D projects $(58 \%)$

- $81 \%$ of the companies show an interest in participating in courses of marketing and commercial promotion

- $76 \%$ would be interested in receiving courses on export trade

- The courses related to sales within the national market, participation in quality awards and local sales, present a demand of $71 \%, 66 \%$ and $65.8 \%$ respectively

\section{Communication of companies with clients and suppliers}

- The $93 \%$ of SMEs prefers to communicate with their clients and suppliers face-to-face

- Only a $34 \%$ uses Internet to communicate

\section{BIBLIOGRAPHY}

1. Renaud S, De Lorgeril M, Delaye J y col: Cretan Mediterranean diet for the prevention of coronary heart disease. Am J Clin Nut 61:1360S-1367S, 1995.

2. Grigoriev AV, Nesterova OA, Olferiev AM: Effect of "Tomatol" on human serum lipoproteins. (Abstr) Atherosclerosis 134: 206, 1997.

3. Kohlmeier L: Antioxidant status and heart attacks in European men. Am J Epidemiol 146: 618-626, 1997. 
4. Graham S, Marshall J, Hanghey B y col: Dietary epidemiology of cancer of the colon in Western New York. Am J Epidemiol 128: 490-497, 1988.

5. Hill MJ: Diet and cancer. A review of scientific evidence. Europ J Cancer Prev 4: 3-42, 1995.

6. White Book of Agriculture and Rural Development http://www.libroblancoagricultura.com/publicacion/pdf /Cap01a10 T2.pdf

7. Spanish Ministry of Agriculture http://www.mapya.es/ es/alimentacion/pags/Denominacion/resultado1.asp

8. OllC http://www.internationaloliveoil.org/

9. Salcilio, Cosimo and Ruggiero, Giuseppe, Relationship between territorial development and technological innovations in the olive-oil sector. University of Bari. Dept. of Engineering and Management of the Agricultural, Livestock and Forest Systems.http://www. pmkv.fi/RuralDevelopmentEngineeringWorkshop/pap ers/CosimoSancilio.PDF

10. EU http://europa.eu.int/comm/agriculture/qual/en/it_en. htm

11. Autonomous Unit for Olive Oil Subsidy Control, Greek Association of Olive Mill Owners
12. EU http://europa.eu.int/comm/agriculture/qual/en/el en. $\mathrm{htm}$

13. Castro, C., Guerreiro, M., Calderira, F. and Pinto, P. "Aspectos Generales del Sector Oleícola en Portugal", OLIVÆE, 66, April 1997, and EU http://europa.eu.int/ comm/agriculture/qual/en/pt en.htm

14. OIIC http://www.internationaloliveoil.org/ and UE http://europa.eu.int/comm/agriculture/qual/en/fr_en.h tm

15. FAO, average 1989-97 and DIE, Agricultural Statistics Summary and OIIC.

"This article has been carried out with support from the European Commission, Priority 5 on Food Quality and Safety (Contract number FOOD-CT-2004-505524 Specific Targeted Project), 'Setting up a network of Technology Dissemination Centres to optimise SMEs in the olive and olive oil sector'. It does not necessarily reflect its views and in no way anticipates the Commission's future policy in this area.»

Recibido: Agosto 2004 Aceptado: Febrero 2005

\begin{tabular}{|c|c|c|c|c|}
\hline & & NNEX I & & \\
\hline $\begin{array}{l}\text { Company } \\
\text { name }\end{array}$ & & & & \\
\hline Contact person & & & & \\
\hline Phone number & & & & \\
\hline Fax number & & & & \\
\hline E-mail & & & & \\
\hline Full Address & & & & \\
\hline Country & & & & \\
\hline Number of staff & $1-5 \square \square$ & $6-50 \quad \square$ & More than 50 & $\square$ \\
\hline Activity sector & Producer $\square$ & Packaging $\square$ & Distribution & $\square$ \\
\hline Turnover & $0-1 M \in \square$ & $\begin{array}{c}1-5 M \in \\
\square\end{array}$ & $\square^{\text {More than } 5 \mathrm{M} \in}$ & \\
\hline
\end{tabular}


1 Mark the information technologies that you have got in your company. Please mark in the appropriate boxes

- Personal Computer (PC)

- Internet connection

- E-mail

- Company web page

- Management programmes (databases, spreadsheets, word processing tools)

- Management accounting and sales management programmes

- Web pages design programmes

- Graphic design programmes

2 In relation to the use of computers, Internet and e-mail in your company, what of the following statements do you agree with? Please mark in the appropriate boxes

- We use computers, Internet and e-mail quite often

- We use computers, Internet and e-mail very little

- They improve company competitiveness

- It could improve public knowledge of products and the company image

- It could facilitate contact with clients and suppliers

- It could facilitate contact with Public Service Departments and government

- It could be used to obtain useful information for the company

- I think implementation, maintenance and training in the use of these tools is an expensive commitment for my company

- Clients and/or provider do not use these new technologies

- It may cause hazards due to computer viruses or security breaches of the network.

3 Do you think you need to improve your knowledge about any of the following aspects? Please mark in the appropriate boxes

- Internet browsing and access

- E-mail use and application

- Web page design

- Use of word processing tools, spreadsheets and databases

- Use of management and accountancy programmes 
4 What kind of information do you search for (or would you like to search for) on the Internet. Please mark in the appropriate boxes

- Public Administration grants and subsidies

- Research projects, patents and scientific journals databases

- Press news, monthly information bulletins and distribution lists

- Legislation and regulations information

- Technologies and know-how

- Market prices

- Clients and suppliers directories

- Courses, conferences, trade fairs and on line courses

5 About legislation and alimentary regulations, would your company need to improve its knowledge in any of the following ones. Please mark in the appropriate boxes 
7 What of the following quality systems have been introduced in your company? Please mark in the appropriate boxes

- Hazard Analysis Critical Control Point System (HACCP)

- ISO 9001 (Quality Management Principles)

- ISO 14001 (Environmental Management)

- Traceability system

- Others (Please specify)

- None

8 Which of the following characteristics apply to your company? Please mark in the appropriate boxes

- Your product belongs to a protected designation of origin

- Your product belongs to a geographical indication

- Your product belongs to an organic/biological production

- You carry out periodical physical-chemical, biochemical and microbiological controls

- You are interested in applying new technologies in production processes

- You have two-phase centrifugation systems (only mills) 
9 What of the following activities are you interested in? Please mark in the appropriate boxes

- Specialization in food technologies

- Participation in research projects or collaborate with Institutes or Government Research Centres

- Preservation techniques to increase product shelf life

- Sensorial analysis: training courses on olive oil and table olive tasting

- Quality improvement

- Analytical measurements in quality control

- Processing technologies

- Local and regional sales

- Participation in quality awards

- National sales (all over the country)

- International sales (export trade)

- Marketing and promotion

10 How do you buy/sell your products and contact your customers/providers? Please mark in the appropriate boxes

- Through intermediaries

- By attending trade fairs

- Through direct contact

- In the Internet

11 European Union Technological Dissemination Centres Network for Olive Oil and Table Olive (TDC-OLIVE) will offer free training courses, the option of participating in national and international food fairs and exhibitions, and receiving our scientific and technological assessment, as well as bulletins and alerts. Your involvement in the project would imply no obligation for you to participate in any of the above mentioned activities.

- Would you be interested in getting involved in TDC-OLIVE?

- I prefer to receive information on paper

Please, let us know any doubt, proposal or suggestion you might have. Your comments will be very much appreciated

Thank you very much for your co-operation 